z 1948 r. (Vladimir Kindl) oraz elementom konstytucyjnym w ABGB (Karolina Adamova), zagadnieniom przynależności państwowej jako przedmiotowi zainteresowania ABGB (Marek Stary), rzymskich korzeni kontraktów realnych w ABGB (Michal Skrejpek) i recepcji rzymskiego systemu kontraktów (Jiri L. Bíly), pojęciu własności (Ondrej Horak), posiadania i dobrej wiary w prawie rzymskim i współczesnym czeskim prawie cywilnym (Petr Dostalik), historycznym korzeniom i współczesnym regulacjom kary umownej.

Zaprezentowano także wystappienia poświęcone problematyce umów o pracę w ABGB i prawie przemysłowym (Ladislav Vojaček), analizie pojęcia osobowości prawnej w pierwszej połowie XIX w. (Karel Beran), prawnonaturalnym aspektom ABGB (Pavel Maršalek), wpływom prawa kanonicznego na rozwiązania w zakresie prawa małżeńskiego w ABGB (Jiři Tretera, Záboj Horák), stosunkom majątkowym małżeńskim (Ivana Starä), prawnej ochronie sierot (Pavla Slavičkova), położeniu ludności żydowskiej w świetle przepisów ABGB (René Petraš) oraz prawu spadkowemu (Karel Schelle).

Większość referentów, wśród których dominowali czescy uczeni, akcentowała w swych wystapieniach znaczenie ABGB i jego wpływ na rozwój prawa na terenach czeskich i słowackich. Jak wyżej wspomniano, interesująco zaprezentowano wystapienia dotyczące prób kodyfikacji prawa, podejmowanych w podobnym jak w Polsce okresie. Warto podkreślić, że nawet $w$ wystąpieniach poświęconych szczegółowym kwestiom prawnym odnaleźć można było bardzo ciekawe wątki polskie. W szczególności zwracały uwagę rozważania na temat problemów z powstawaniem czeskiego języka prawnego, widoczne $\mathrm{w}$ pierwszych thumaczeniach kodeksu ABGB na język czeski, podczas których podpierano się, a niekiedy wprost używano terminologii polskiej, jak w wypadku kłopotów z thumaczeniem pojęcia ,eigentum”, gdy sięgnięto wprost po polski termin „własność”. Do polskiej terminologii sięgano także w okresie po II wojnie światowej. Ten niezwykle interesujący wątek zasługuje na uwage także nauki polskiej, która zagadnieniom tworzenia się nowoczesnej polskiej terminologii prawniczej nie poświęcała dotychczas zbyt wiele uwagi. Na marginesie warto w tym miejscu przypomnieć postać niemal zapomnianego prawnika z Galicji, Michała Stojowskiego, którego tłumaczenie ABGB z 1811 r. miało w tym zakresie duże znaczenie.

Konferencja była ostatnim spotkaniem po cyklu jubileuszowych konferencji odbywajacych się między innymi w Wiedniu, Krakowie, Frankfurcie nad Menem, poświęconym jubileuszowi austriackiej kodyfikacji. Organizatorzy, którym udało się stworzyć podczas obrad bardzo życzliwą, a zarazem skłaniającą do naukowej dyskusji atmosferę, przygotowują publikację wszystkich wygłoszonych podczas spotkania referatów.

DOROTA MALEC (Kraków)

\title{
I SYMPOZJUM HISTORYKÓW PAŃSTWA I PRAWA POLSKIEGO W KRAKOWIE (16 stycznia 2012)
}

Na Zjeździe Katedr Historyczno-Prawnych w Zegrzu w 2010 r. prof. Wacław Uruszczak przedstawił propozycję odbywania odrębnych konferencji historyków prawa polskiego. Taki był początek inicjatywy, która zaowocowała zorganizowaniem przez Katedrę Historii Prawa Polskiego oraz Katedrę Historii Administracji i Myśli Administracyjnej UJ w dniu 16 stycznia 2012 r. I Sympozjum Historyków Państwa i Prawa Polskiego w Krakowie. Organizatorzy sympozjum początkowo planowali jego odbycie jesienią 2011 r., a zatem w połowie dwulecia dzielącego Zjazdy Katedr Historyczno-Prawnych, jednak z powodu trudności technicznych (wiążących się z zaangażowaniem Uniwersytetu w trakcie polskiej prezydencji w Unii Europejskiej) spotkanie to zostało przeniesione na początek obecnego roku kalendarzowego. Idea, 
która przyświecała organizatorom, było umożliwienie prezentacji na wspólnej sesji plenarnej dhuższych wystapień (do $30 \mathrm{~min}$.), dotyczących wybranych zagadnień. W związku z rocznicami, które przypadły w roku 2011, jako tematy kluczowe I Sympozjum Historyków Państwa i Prawa Polskiego zaproponowano dwa akty prawne epoki Oświecenia, które w wieloraki sposób wpłynęły na rozwój prawodawstwa, orzecznictwa oraz świadomości prawnej mieszkańców ziem polskich: Konstytucję 3 maja oraz ABGB.

Do udziału w sympozjum zgłosili się uczestnicy z uniwersytetów: Warszawskiego, Ślaskiego, Wrocławskiego, Łódzkiego, Rzeszowskiego, Marii Curie-Skłodowskiej w Lublinie oraz Wyższej Szkoły Finansów i Zarządzania w Warszawie, a także przedstawicielka Uniwersytetu Wiedeńskiego, reprezentująca zarazem Austriacką Akademię Nauk. Wśród wystapień odnotować należy referat prof. Andrzeja Mączyńskiego, kierownika Katedry Prawa Prywatnego Międzynarodowego UJ i byłego wiceprezesa Trybunału Konstytucyjnego. W obradach uczestniczyli także: rektor Krakowskiej Akademii im. Andrzeja Frycza Modrzewskiego prof. Jerzy Malec, prodziekan Wydziału Prawa i Administracji UJ prof. Dorota Malec (która wygłosiła słowo wstępne, otwierające sympozjum) oraz pracownicy i doktoranci katedr historycznoprawnych działających na Wydziale Prawa i Administracji UJ.

Uczestnicy spotkania mieli okazję wyshuchać kilku specjalistycznych referatów i komunikatów z różnych perspektyw naświetlających zagadnienia związane z Konstytucją 3 maja i ABGB. Podczas obrad, sprawnie prowadzonych przez prof. Mariana Mikołajczyka z Uniwersytetu Śląskiego, przedstawiono wystappienia o następujących tematach:

Ustawy okolokonstytucyjne Sejmu Wielkiego z 1791-1792 roku (prof. Wacław Uruszczak, UJ);

Problematyka Kościola katolickiego w konstytucjach polskich (ks. prof. Władysław P. Wlaźlak, UR);

Nauka austriackiego prawa cywilnego w Galicji (prof. Andrzej S. Mączyński, UJ);

Zasady dziedziczenia nieruchomości wedlug $A B G B$ (prof. Józef Koredczuk, UWr);

Kodeks cywilny austriacki (ABGB) a wykonanie zobowiąań pieniężnych w II Rzeczypospolitej (Robert Jastrzębski, prof. UW);

Wplyw zagranicznych kodyfikacji na rozwój $A B G B$ do upadku monarchii austro-wegierskiej (mgr Kamila Staudigl-Ciechowicz, Uniwersytet Wiedeński);

Intercyza w $A B G B$ (dr Dorota Wiśniewska, UŁ).

W dyskusji kończącej obrady sympozjum uwzględnienia doczekały się kwestie poruszone we wszystkich przedstawionych referatach. Głos w dyskusji zabrali prof. Józef Ciagwa, prof. Dorota Malec oraz referenci. Warto odnotować także wystapienie dr. Andrzeja Drogonia, dyrektora katowickiego oddziału IPN, który w związku z rocznicą wprowadzenia stanu wojennego zaprezentował wydany przez tę instytucję kalendarz na rok 2012, poświęcony temu wydarzeniu (egzemplarze zostały rozdane uczestnikom sympozjum). Podsumowując obrady prof. Wacław Uruszczak podziękował osobom zaangażowanym w organizację I Sympozjum HPiPP za podjęty wysiłek, a gościom za przybycie. Wyraził przekonanie o potrzebie cyklicznego odbywania tego rodzaju spotkań, a ponadto poinformował, iż gotowość organizacji kolejnego sympozjum zgłosił Uniwersytet Śląski.

Organizatorzy zdecydowali się ponieść koszty związane z pobytem uczestników I Sympozjum Historyków Państwa i Prawa Polskiego w Krakowie; wsparcia finansowego udzieliła prof. Krystyna Chojnicka, dziekan Wydziahu Prawa i Administracji UJ, a nadto kierownicy Katedr Historii Prawa Polskiego oraz Historii Administracji i Myśli Administracyjnej UJ. Dzięki temu, że zorganizowania kolejnego sympozjum podjęli się obecni na obradach przedstawiciele Uniwersytetu Śląskiego, istnieje duża szansa, że spotkania te przerodzą się w cykliczne fora wymiany myśli przez badaczy zagadnień związanych z przeszłością państwa i prawa polskiego - co też było głównym celem inicjatorów krakowskiego spotkania. 